\title{
Externalities, Learning and Governance: New Perspectives on Local Economic Development
}

\author{
A. H. J. (Bert) Helmsing
}

\begin{abstract}
In spite of growing mobility of production and production factors, economic development is increasingly localized in economic agglomerations. This article reviews three partially overlapping perspectives on local economic development, which derive from three factors intensifying the localized nature of economic development: externalities, learning and governance. Externalities play a central role in the new geographical economics of Krugman and in new economic geography of clusters and industrial districts. The dynamics of local economic development are increasingly associated with evolutionary economic thinking in general and with collective learning in particular. Inter-firm and extra-firm organization has experienced considerable innovation in the last few decades. New institutional devices are based on the notions of commodity chain, cluster and milieu. These innovations introduce new issues of economic governance both at the level of industry and of territory.
\end{abstract}

\section{INTRODUCTION}

If capital, raw materials, products and components can move across countries and to many parts of the globe, thanks to improvements in transport, communications and management technologies, why is there still a case for economic activity to concentrate in agglomerations? The purpose of this article is to review literature on three partially overlapping perspectives on local economic development. These three perspectives broadly correspond to three factors enhancing the localized nature of economic development - externalities, learning and governance. Externalities are well-known phenomena. The significance of learning at the level of firms, clusters and regions is a more recent concern but is rapidly gaining ground. Governance connects the two. Effective governance allows a greater range of externalities to be exploited, while learning enhances local competence for policy.

The article will begin by examining external economies, starting with the work of Paul Krugman, which has become known as geographical economics, and moving on to look at the manner in which the 'New Industrial District' 
literature has conceptualized the contribution of external economies, pointing out some common elements and key differences between these two schools of thought. It will then examine the second source of localized economic growth, namely processes of learning and collective learning, by briefly elaborating on the evolutionary perspective. While processes of learning and collective learning take place at the level of firms and networks of firms, these processes can achieve higher levels of innovative capability when organized at the level of territory or 'milieu'. This leads to the third factor, namely governance. Innovations in economic governance constitute one of the radical changes of our times. The 'modern' corporation was the focus of attention in the early and mid-twentieth century, but in the last few decades, many innovations have emerged in inter-firm and extra-firm organization. New institutional devices are based on the notions of product column, commodity chain, cluster and milieu. These innovations introduce new issues of economic governance not only at the level of the firm and industry but also at the level of territory.

\section{EXTERNALITIES}

\section{Geographical Economics}

Krugman is one of a number of economists who have contributed to the growing recognition of the localized nature of economic growth. His work stands somewhat apart from that of others and has been given the label of geographical economics. He considers the incorporation of space as the fourth (and possibly final) wave of the increasing returns/imperfect competition revolution, the first three waves being industrial organization, new trade theory and new growth theory (Krugman, 1998a). Krugman argues that to understand international trade, one must understand why industries tend to concentrate geographically. Generally firms will locate in areas with the largest demand. Because of the potential for increasing returns, generated by economies of scale, firms prefer to supply other areas from this initial location. Sufficiently low transport costs will make this possible. The area of largest demand will draw other firms, which adopt the same logic, and this reinforces its attractiveness. Producers will prefer to locate where the demand is large and where the supply of inputs is particularly convenient. The agglomeration of economic activity reflects processes of cumulative circular causation whereby 'activities tend to cluster where markets are large and markets become larger there where activities cluster' (Krugman, 1995). Factor mobility further contributes to circular cumulative causation where centre regions grow at the expense of peripheral ones. The larger the potential economies of scale, and the lower the transport costs, the stronger will be the tendency towards agglomeration of production, with economies of scale the principal cause of concentration. 
This phenomenon is considered to occur primarily at the inter-regional level, consisting of large economic units (Krugman, 1991: 70-1).

Krugman looked at another process of agglomeration, that based on external economies. This process occurs mainly at the local level. Krugman relies on the classical Marshallian type of external economies, in which labour market pooling is seen to be a primary cause. Agglomeration is attractive for workers with specialized skills as pooling permits them to switch employers, while firms are able to recruit additional workers. Under conditions of increasing returns to scale and knowledge-uncertainty, both can benefit. A second source of external economies is generated by specialist inputs and services. Assuming economies of scale, specialist inputs can be made at higher scales in a cluster of firms. Thanks to the larger size, specialists can also support a greater range of inputs. These are called market size effects, and they operate through both backward and forward linkages. The third source of external economies comprises knowledge and information flows: a concentration of firms facilitates the flow of information and knowledge exchange. These are considered to be pure or technological knowledge spillovers. Krugman excludes these from his models with the argument that knowledge flows cannot be easily traced. These three sources of external economy constitute centripetal forces that generate geographical concentration. Like Myrdal (1957) and other distinguished predecessors, Krugman recognizes centrifugal forces, which tend to disperse economic activity. Here he refers in particular to immobile factors, land rents and pure external diseconomies (Krugman, 1998a, 1998b).

In his early work (Krugman, 1991, 1995), Krugman stressed the importance of the market size effect as contributing to geographical concentration. In his more recent work, he expects this to be less important than other sources of agglomeration at least where cities are concerned. 'Big cities may be sustained by increasing returns that are due to thick labor markets, or to localized knowledge spillovers, rather than those emerging from the interaction of transport costs and scale economies at the plant level' (Krugman, 1998a: 172).

The specialization of an area in a particular industry may itself be a historical accident. Whatever the reason for the initial location of a cluster, once a pattern of specialization is established, increasing returns set in and the pattern of specialization becomes 'locked in' by cumulative gains from trade. There is strong path dependence in the pattern of specialization and of trade. Trade and location are integrated. When an industry happens to get a head start in a particular region, that region will continue to specialize in that industry. This specialization has cumulative advantages but it may also have disadvantages. The region may 'overspecialize', organizing all its resources and institutions around one particular industry and this may lead to a 'crowding out' or lack of attention to other industries. Specialization may make a region prone to random external shocks, while shifts in demand may render the entire industrial base obsolete. Thus, while specialization may have advantages, the other side of the coin is vulnerability. 


\section{New Industrial Geography: Industrial Districts}

In the mid-1980s a body of literature emerged on 'new industrial districts' (NIDs) - new, because the original concept was formulated by Marshall. The NID literature sought to explain the economic success of clusters of firms in peripheral areas in developed and developing countries. Welldocumented cases in the latter category are found in Brazil (Schmitz, 1995a, 1999b), Mexico (Rabellotti, 1995, 1999), Peru (Visser, 1996, 1999) and India (Cawthorne, 1995; Das, 1998; Knorringa, 1996, 1999; Nadvi, 1996). Industrial districts span a diversity of sectors that range from basic consumer goods, such as shoes, clothing and knitwear, to intermediate products and consumer durable goods. A number of these 'districts' were booming while large firms in the same sectors in well-established regions were in difficulties and laying off workers. What was behind the success of these NIDs? There are a number of factors and these may be summarized as follows (also see Helmsing, 1999a).

Firstly, new technologies introduced greater production flexibility (Piore and Sabel, 1984). Computer controlled machine and related information technologies allow firms to switch design specification and machine configurations more accurately and more swiftly. Flexible specialization is based on the manufacture of custom-made products using multi-purpose technology and flexible production methods, operated by skilled workers. Small production runs are feasible as re-tooling times are short and costs are low. Firms can tailor products to specific demands. As a result products can become differentiated. Innovation into product designs becomes a challenge and a way to avoid price competition. While 'fordist' production needs stable and homogeneous mass markets, flexible specialization thrives in rapidly changing and niche markets.

Secondly, clustering of firms may facilitate the emergence of a division of labour in the manufacture of various components and parts whereby each firm becomes a specialist supplier for other firms. Organizational deepening can take place. This generates external economies. Small firms, which would lack internal economies of scale in trying to cover all operations efficiently, compensate that disadvantage by drawing on other firms in the cluster. A cluster also offers a greater diversity generating economies of scope. Several authors have noted that external economies may also be generated in the transaction sphere (Scott, 1988), a phenomenon noted especially in developing countries (Visser, 1996, 1999; Weiland, 1999). Clusters may attract traders who are interested in buying but unlikely to approach individual businesses. Traders in inputs may offer a greater variety as they expect more business.

Thirdly, clustered firms can gain additional advantages by inter-firm cooperation and by joint action. Schmitz (1995a, 1995b, 1999a) called this 'collective efficiency'. Whilst agglomeration economies are relevant, they are generally available to all firms in an agglomeration. What is more important, according to Schmitz, is the fact that clustering permits firms to 
organize themselves and to provide critical services, which otherwise would not be forthcoming. Firms individually may be too small to provide these inputs themselves, while the market may be either too small to allow for such inputs to be bought in, or they may simply be unable to provide them (inputs with public good character). Clustering helps to solve this problem, since advantages are generated by deliberate and purposeful joint action. This can involve inter-firm vertical co-operation (with suppliers and with customers) and different forms of horizontal co-operation. More recently a further distinction has been made between 'passive' and 'active' collective efficiency (Nadvi, 1996, 1999). Active collective efficiency denotes joint action aspects in both production and distribution: as competition gets more intense, passive collective efficiency is not enough. Firms have 'to shift gear' and seek inter-firm co-operation as a means of becoming more competitive (Schmitz, 1999a). Joint action may vary in terms of the number of participating firms (bilateral or multilateral) and may be oriented in a vertical or horizontal direction (ibid.). In a more recent work Schmitz continues to stress the importance of joint action but has become more appreciative of local external economies (Schmitz, 1999b), which may arise from continued private investment by firms in the cluster. The benefits of this spread through technological spillovers or seepage and through the movement of trained workers to other firms. Contrary to neo-classical perceptions that such external effects would lead to under-investment, Schmitz argues that firms will continue to invest as they are not only providers of such external economies but also benefit from investments by other firms in the cluster.

Firms in a cluster can agree on common institutions, such as norms and standards for the specification of products and inputs. Firms in a district may agree amongst themselves to conform to certain formal or informal codes of conduct, trade practices and cultural norms. These tend to reduce costs (Storper, 1990). The creation of common institutions that lower transformation and/or transaction costs, such as technology information centres, quality control, credit consortia, and common norms and standards for inputs and products can only be realized if a certain geographical concentration in the industry has emerged. It is important to note that while this generates advantages, these advantages cannot be easily seen as an initial cause of geographical concentration. Once a geographical concentration has begun to organize itself as a cluster these untraded advantages may potentially be within reach.

Several authors have recently found that increased exposure to (new) competition induces firms to engage in more inter-firm co-operation (Knorringa, 1999; Rabellotti, 1999; Schmitz, 1999b). In most instances, this applies to vertical co-operation with suppliers and sometimes with contractors. Horizontal co-operation, required to increase efficiency at the meso-level, is less frequent. Catalysts are needed, such as those found in the ceramics industry studied by Meyer-Stamer (1998). However, potential catalysts do not always succeed in playing their role, as in the case of the 
state government in Rio Grande do Sul in relation to the shoe industry analysed by Schmitz (1999b). It would seem appropriate to add that this inter-firm co-operation refers to more advanced clusters.

Collective efficiency contributes to economic performance. Rabellotti and Schmitz (1999) and Schmitz (1999a) observed a positive association between collective efficiency and economic performance of firms in clusters in Mexico, Brazil and Italy, using several performance indicators. Elsewhere, Schmitz argues that clustering may be one of the factors contributing to increasing returns of scale and to competitive advantage for firms in clusters (Schmitz, 1999b). Clearly clustering and NIDs may confer advantages on small firms, but do effects always occur and what about large firms? Empirical findings generated in the 1990s show there to be a lot of differentiation both between and within clusters.

\section{Differentiation Within and Between Clusters}

A first stock-taking of the NID model was conducted by Humphrey (1995). He noted several important problems. Most definitions were restricted to small firms, obscuring the role that large firms play in districts. The emphasis on inter-firm relations has diverted attention away from researching the internal structure and dynamics of firms. As has been argued by many, externalization and subcontracting is but one response to increased competition and uncertainty. Furthermore, entrepreneurial competence is assumed but cannot always be taken for granted in small firms. The industrial district model focused heavily on inter-firm relations within districts but failed to be specific on external linkages. Schmitz added that differences in firm size might have implications for the characteristic socioeconomic features of industrial districts, namely competition with cooperation, joint action, and embeddedness (Schmitz, 1995b). As argued earlier by Asheim (1992), intra-district firm dynamics may be altered when large firms emerge within clusters or penetrate clusters from the outside.

More recently, studies have offered new evidence on differentiation between and within clusters. A number of these were published in a special issue of World Development (September 1999). Taken together, these studies contribute several important findings. First of all, there seems to be a growing consensus that there are many different types of clusters, not only in advanced countries (as elaborated by Markusen, 1996) but also in developing countries. New typologies of clusters are needed to deal with the fact that the alleged advantages of clustering and features of industrial districts are not always found. In reviewing African case studies, McCormick (1999) argued that there are at least three different types, defined in terms of stages in the clustering-cum-industrialization process. The first is the (pre-industrial) 'groundwork cluster' in which micro and small enterprises dominate, many of which are survival oriented. Conditions 
are highly competitive, there are no internal economies of scale, and the lack of inter-firm relations prevents deepening of the division of labour. Cluster advantages are limited to market access. The second is the 'industrializing cluster', which is still primarily local market oriented but which contains more advanced units. This type enjoys limited external effects. The third category is the 'complex industrial cluster', which contains firms oriented towards national markets and exports. This cluster comes closest to the theoretical ideal type. Case studies record joint action in this type of cluster, albeit ad hoc and on a limited scale. Most African clusters enjoy only (limited) passive cluster advantages (see also Pedersen et al., 1994).

This classification bears some resemblance to the one proposed by Altenburg and Meyer-Stamer (1999), based on an examination of Latin American clusters. They proposed a threefold typology. The first, the 'survival cluster' of micro and small enterprises, roughly combined the first two specified by McCormick. These authors also considered cluster advantages to be limited and largely passive. Their second type refers to more advanced and differentiated mass producers, which were typically established during the era of import substitution. Their third type has no counterpart in the African classification, consisting of clusters of TNCs. Altenburg and Meyer-Stamer draw on cases in Central America and Mexico, where NAFTA has triggered a re-orientation of foreign investment and attracted new foreign investment in the form of core suppliers.

A second important finding of the recent studies is the fact that there is frequently considerable differentiation between firms within a cluster. Clusters are not homogeneous in terms of firm characteristics, nor do they remain static over time. Some firms benefit more from clustering than others. Agglomeration economies accrue, in principle, to all firms and hence are an unlikely cause of differentiation. The question therefore arises whether active collective efficiency helps to explain these differences. Studies by Rabellotti and Schmitz (1999) and Schmitz (1999a) demonstrate that there is a positive association between inter-firm co-operation as a component of active collective efficiency and the economic performance of firms in the researched clusters. This applies especially to medium-sized firms. Rabellotti and Schmitz found that large firms draw less on the cluster while small firms engage less in joint action. Knorringa (1999), examining the footwear industry in Agra, India, found market channels to be an important differentiating factor within the cluster.

\section{Reflections}

The exchange and cross-fertilization of ideas between Krugman and NID authors and economic geographers generally have been complicated by differences in approach and by the manner in which the two have interacted. There are important common features and complementarities between 
Krugman and the NID literature (cf. Boddy, 1999; Martin and Sunley, 1996). Both Krugman and NID, for instance, stress the importance of clustering and draw on Marshall to identify the different types of externalities involved. The technological dynamism of clusters received little attention from Krugman, and NID authors have only recently begun to look into this (for example, Asheim, 1996). Bell and Albu (1999) reviewed a number of NID studies and found them to be lacking a learning orientation. Furthermore, labour market externalities are identified by both, but the NID literature pays less attention to them. In fact, flexible specialization was found to cause labour market segmentation.

Krugman emphasized the path-dependent nature of regional specialization and pointed to the dangers of a lock-in when high levels of specialization are reached. Initially, the advocates of flexible specialization heralded NID as a challenge to large-scale 'fordist' production. Since the mid-1990s, more realistic positions have been taken. Clusters may be just a phase in industrial development. There is also complementarity, for example, in that Krugman connected clustering with increasing returns and with international trade. With regard to the former, Schmitz (1999a) has very recently made an attempt to link collective efficiency with increasing returns. Certainly initially, the link between clusters and international trade received less attention in the NID literature. As observed by Humphrey (1995) the NID research was inward oriented, looking at what happened within the clusters, and ignoring their external nexus.

However, there are also important differences. The NID literature has unearthed a greater variety of traded externalities, emphasizing particular transaction advantages. The emphasis of NID literature has shifted over time, giving greater weight to untraded externalities, those arising from collective efficiency and from historical and social embedding. Krugman ignored these for reasons of methodology. A closely related point is that for Krugman external economies are sufficient, whereas the NID literature attaches great importance to active collective efficiency — joint action by firms and supporting public agencies and local governments.

What may be an 'accident of history' in advanced countries, studied by Krugman, may be a heavily structured 'product of history' in many developing countries, especially those with a colonial past. This is what centre-periphery theorists have been arguing for many years, using a wide array of theoretical strands and orientations, and producing analyses of centre-periphery structures which were more varied and complex than the factors identified by Krugman.

Increasing returns and external economies confer upon the constituent firms some specific local competitive advantages. However, Krugman is critical about the notion of competitiveness per se (Krugman, 1994). Others, particularly new economic geographers, have asked whether strategic trade policy can be employed to create such local 'competitive advantages' (see, for example, Martin and Sunley, 1996). If clusters are proof of the working 
of external economies, then such clusters would help to define which industries should be supported. In this way the controversial trade policy issue of targeting may be resolved. These authors conclude that: 'In effect what Krugman seems to be suggesting, though he does not use the term explicitly, is that the only justifiable form of industrial (trade) policy is in fact regional industrial development policy' (Martin and Sunley, 1996: 282). One could add here that instead of 'picking winners' such a policy would aim to generate positive externalities at the level of the cluster. Regional industrial policy would then have the potential to foster national competitive advantage. This broad contention has already been formulated by Porter $(1985,1990)$.

Finally there is a question which intrigued Krugman but which the NID literature generally sidesteps: why do clusters arise in the first place? Krugman sees a general tendency to concentrate production so as to gain economies of scale, with large firms co-locating because of the external economies. Circular cumulative causation does the rest. The NID literature usually begins with small firm clusters. Less attention is paid to the question of why clustering originally occurred, that is, before flexible technology made it possible for small firms to gain additional passive external economies and eventually organize themselves to develop active collective efficiency advantages. There may be other unrelated causes. The NID literature is rather silent on the wider (inter) regional implications of NID.

\section{KNOWLEDGE AND COLLECTIVE LEARNING}

In the early 1980s Nelson and Winter formulated their evolutionary perspective on economic change. One of their central propositions is that firm behaviour can be explained by the routines they employ; knowledge of the routines thus lies at the heart of understanding the behaviour (Nelson and Winter, 1982: 128). The more a routine involves tacit knowledge the more difficult it is to imitate, especially from a distance (ibid.: 124). Firms will try to codify their routines, so as to reduce the problems of replication. Codification detaches knowledge from its immediate local context, and makes it widely available, but there are limits to the degree to which such codification can take place.

Routines are changed when a problem occurs and standard responses no longer work. However, firms have limited search capabilities and are subject to bounded rationality: the implied learning may lead to incremental innovation, as uncertainty can be contained by making changes in small steps. Furthermore, successful innovation draws on other existing and welltested sub-routines, further enhancing the incremental character. Learning processes are cumulative; routines and learning introduce path dependence: 'The routines of today are based on those of yesterday, as much as those of tomorrow are related to those of today' (ibid.). 
This new evolutionary thinking gained influence in local and regional studies in the late-1980s and early-1990s. A number of new ideas were built up which together constituted an emerging perspective on local economic development. Two issues were central to this new perspective: the first was based on the proposition that tacit knowledge exchange needs spatial (as well as organizational or cultural) proximity; the second referred to the territorial context of processes of learning and knowledge creation. Collective learning became a new guiding concept, with emphases and analytical entry points varying. Some started from the perspective of firms, others drew on emerging literature on the national innovation system and gave this notion territorial hands and feet; still others developed the notions of 'learning region' and 'innovative milieu'. These theoretical developments can be identified as major features of a new emerging perspective on local economic development.

\section{Learning and Collective Learning}

In the competence theory of the firm, a firm is defined as a repository of productive knowledge (rather than a nexus of contracts). Learning by doing is central to maintaining and renewing competencies: 'Core competencies are the collective learning in the organization, especially how to coordinate diverse production skills and integrate multiple technologies ... Core competencies do not diminish with use but are enhanced by it' (Lawson, 1999). In this view, product market competition is merely a superficial expression of a deeper competition over competencies. Conceiving the firm in terms of core competencies suggests that inter-firm competition, as opposed to interproduct competition, is essentially concerned with the acquisition of knowledge and skills (ibid.).

As markets become liberalized and firms are exposed to international and 'new' competition, they need to develop a dynamic capability to renew, augment or adapt their competencies in order to maintain economic performance. Innovation and learning are central and involve combining diverse technological, organizational and market knowledge. Lawson and Lorenz (1999) elaborate on three central ideas from organizational learning. First, learning depends on the sharing of knowledge; this knowledge is mostly tacit and embodied in organizational routines and procedures. Second, new knowledge depends on combining diverse knowledge. Third, firms may find it difficult to make effective use of new knowledge because they face resistance to changes in their existing routines and procedures in which knowledge is embodied - the phenomenon of organizational inertia. When diverse knowledge is recombined the associated tacit knowledge must be made precise and discursive. This provides a basis for the redesign of routines, which in turn creates the new tacit knowledge needed to work under the new conditions. 
Firms have a limited capacity to undertake a specific range of activities. Choices must be made. Complementary activities requiring similar knowledge may be best co-ordinated within the firm, while activities based on non-similar knowledge call for co-ordination through formal or informal co-operation between firms. Thus, when firms want to invest in new products or processes in response to new competition, they encounter problems because they lack the knowledge to efficiently undertake the complementary activities needed to produce and market them. Alternatively, a firm may be able to produce cheaply but lack the competence to design its products in line with the latest trends. Inter-firm co-operation becomes a key to address this issue. Lawson and Lorenz argue that in regions where this complementary knowledge is available, firms have a better chance to learn and develop new routines and competencies. Skilled labour, specialist services and inter-firm co-operation create a capability in a region or cluster to renew and augment the competencies of firms. This requires a social context, and a common language and culture to facilitate exchange, and the region may provide these.

Camagni (1991) approached the problem somewhat differently, arguing that uncertainty is the key. A firm has to engage in all sorts of special functions in order to cope with a range of uncertainties. It may have difficulties in gathering, assessing and interpreting information about what is going on around it. The firm may find it difficult to assess outcomes of alternative courses of action, which also depend on actions by other players over which it has little control. Camagni argued that a firm has two options for coping with these problems: the milieu, and the network.

By being part of an agglomeration, which Camagni called a milieu, a firm can greatly expand its capacity to learn. The milieu reduces uncertainty by increasing transparency, thus constraining opportunistic behaviour. It gathers, organizes and exchanges information. It provides additional signalling, articulates needs of firms, and facilitates co-ordination of actions. Learning takes place via supply chain linkages (that is, supplier and customer relations), via mobility of skilled labour between the firms, and, last but not least, via spin-off activity (creation of new start-ups). It also involves (i) imitation and reverse engineering; (ii) informal knowledge exchange via 'cafeteria effects', and (iii) specialist services. In short, the milieu enables collective learning (Camagni, 1991; Lawson and Lorenz, 1999).

Camagni argues that proximity is central to the effectiveness of the milieu. In the first place, human capital resources are often highly mobile within the local area but quasi immobile with respect to other areas. Furthermore, specialization and geographical concentration provide a dense local labour market but offer few opportunities outside the area. Second, the interaction generates an intricate network of mainly informal contacts among local actors, creating an 'industrial atmosphere'. Synergy effects stem from a common cultural, and similar psychological and often political background (Camagni, 1991: 133-4). 
The milieu is one mechanism for learning and for the reduction of uncertainty. The network is another. This may be defined as 'a close set of selected and explicit linkages with preferential partners in a firm's space of complementary assets and market relationships, having as a major goal the reduction of static and dynamic uncertainty' (Camagni, 1991: 135). Thus, instead of exploiting local synergies and collective learning mechanisms, firms engage in selective networking on a trans-regional or even transnational basis. They may engage in joint ventures, strategic alliances, consortia, technical co-operation, licensing and franchising arrangements. In these ways, firms obtain access to important complementary assets, markets and technologies without having to incur organizational or locational costs, and they also free themselves from the limits of localized (and internal) competence.

Whether milieu or network is adopted depends, among other factors, on the initial conditions in the area, firm size and structure, the degree of competition and co-operation, local industry dynamics and differentiation. In general, one could argue that patterns of learning are different for small firms than for large ones. Large firms are more autonomous, can mobilize internal resources, have their research and development (R\&D) budgets, can engage in strategic alliances, and so on. Small firms lack the resources to maintain a dynamic capability on their own and need to draw on external resources and support. This need not be public resources but can take the form of relations with other firms, large and small. Hence, for small firms the local milieu is an important mechanism for learning. The milieu is openended and relies on 'pure' externalities, while networks are selective and closed and turn externalities into club goods. From here the relative strengths and weaknesses of these two new operators can be inferred. The milieu, involving larger numbers of participants, is relatively stronger in dealing with monitoring, assessment and trans-coding of information, while networks, more selectively composed, are more effective in relation to decision and control gaps.

To summarize, the presence of local collective learning enhances the capacity of local firms to learn to adapt and to innovate. In comparison to other firms, they can tap into a larger resource base and draw on additional local processes to renew and augment their competencies. The local milieu offers the capability for sustained competitive advantage. Maskell and Malmberg (1999) quote Foss, who argues that there are two requisites for this to happen: first, that the local capability cannot simply be purchased and transferred elsewhere (it would have to be regionally specific); and second, that it cannot easily be replicated elsewhere (imperfect imitation). Capabilities rooted in a person or in a firm may be easily bought, but capabilities residing in inter-personal connections and in localized inter-firm networking cannot. On the question of replication, Maskell and Malmberg argue that the creation of regional or local capability entails tacit knowledge that goes with any (codified) knowledge creation. This tacit knowledge 
prevents perfect replication, in spite of the potentially global distribution of the relevant codified knowledge.

Lawson (1999) goes one step further, arguing that if firm-level learning takes place to overcome co-ordination problems, then regional collective learning can be seen as the emergence of basic shared knowledge and procedures amongst a group of (geographically close) firms which facilitates co-operation and problem-solving. Key factors include: a common language for talking about technological and organizational problems; shared or partially overlapping technological/engineering knowledge; and shared organizational knowledge of how to manage and divide responsibilities and modalities of collective decision-making.

Preconditions for collective learning are common, regional, culturallybased rules of behaviour, a language of engagement and collaboration, and accepted but tacit codes of conduct between firms, which enable the development of trust, itself essential for innovative collaboration. A local 'collective agent' of some kind often plays a pivotal role in enhancing these preconditions.

In Lawson's term, the milieu acquires its own competencies. These are understood here as emergent properties of social activity. 'Some level of organization can be said to be emergent if there is a sense in which it has arisen out of some lower level but is not reducible to it or predictable from it' (Lawson, 1999: 157). Regional competencies arise out of the interaction between individuals and organizations. Processes of labour mobility between organizations, birth and death rates of firms (via spin-offs or vertical disintegration of firms) fall outside the purview of firm-level competencies but become central to the analysis of regional competencies. They all have spatial proximity in common: 'Taking all these factors together, the region, as a productive system, may be differentiated as an ensemble of competencies that stretches both through space and across organizations, and contains a degree of coherence in virtue of the nature of (localized) interaction constitutive of it' (Lawson, 1999: 157).

A milieu, according to Maillat (1995), also has broader inter- and extrafirm institutional properties. There must be a collection of players consisting of firms, research and training institutes, and local authorities, which must have relative decision-making independence and relative autonomy in making strategic choices. There must be an interaction logic that derives from co-operation: players must be interdependent in order to take greater advantage of existing resources. There must be a learning dynamic that is manifested by the players' ability, formed over time, to modify their own behaviour and to implement new solutions to achieve changes in their environment.

A milieu becomes innovative when local actors begin to exploit advantages of collective learning and to adjust their own actions to that end - in other words, when 'interactions amongst economic agents develop as they learn about multilateral transactions that generate innovation 
specific externalities, and as the learning processes converge towards increasingly efficient forms of joint management of resources' (Maillat, 1995: 161). When a milieu succeeds in organizing its resources and coordinating and linking economic, cultural and technological structures, it becomes capable of creating new ways of productively combining these resources. Innovative capability depends not only on new combinations of existing resources but also on linking up with external resources. The milieu must therefore develop the higher order competence to open up to the rest of the world and mobilize external resources.

\section{Evolutionary Trajectories of Local Economic Development?}

Researchers have been preoccupied with the question of the long-term sustainability of NIDs. A cluster may decline from within as a result of internal differentiation processes, as some firms are likely to be more successful in capturing the gains of NID than others. Internal and/or external acquisitions and mergers, under the impact of heightened competition, can cause further internal differentiation. What are the dynamics of industrial districts, what trajectories are possible? There is general agreement that one of the major changes affecting clusters is the increasing international competition as countries open up their economies. What is the capacity of a cluster to respond to external changes and what is the role of external agents?

Humphrey (1995) was concerned about the demand side and suggested in that context the notion of global commodity chains. Global chains organize global markets and consist essentially of sets of networks, some of which may be extended into existing industrial districts:

\footnotetext{
The trajectory of development of the cluster will be the outcome of an interaction between the firms and institutions in the cluster and the other elements in the commodity chain. Whether or not insertions into a commodity chain will create development potential for a cluster will depend on both its position in the chain and the capacity of firms and institutions to make use of or create sources of competitive advantage and opportunities for upgrading. (Humphrey, 1995: 158)
}

The kind of integration varies by type of chain, and according to the demand characteristics of the products. The sustainability of a NID depends on the external nexus and its implications for the industrial organization of the cluster.

Others consider the endogenous technological capability of NIDs essential. If technological change and innovation are the driving forces of competition, how do SMEs acquire such capability? Authors including Asheim (1996) and Capello (1999) draw on collective learning as the key to SME endogenous innovative capacity. According to Asheim (1996) the early version of NID emphasized the traditional Marshallian features - by 
clustering, small firms compensate their lack of internal economies of scale. By specialization and deepening the division of labour, each firm replicates specialized activities integrated within the organization of a district, gaining external economies of scale. This is, in Asheim's view, a rather Fordist conception and too much centred on static locational efficiency. Such a system would be able to generate incremental technical change along the existing technological trajectory (benefiting from economies of scope): however, once such extended division of labour has been achieved there is the real danger of 'lock-in', when firms would lack the required flexibility for more radical change and be unable to change course. Furthermore, once locked-in, the district as a whole may find wage competition a more convenient and less risky option to maintain competitiveness. This would mean that the NID would fall back onto the 'low road of industrialization'.

To prevent itself from falling into that trap, a NID would have to increase its technological capability and transform itself into a 'learning region'. Collective learning would be the answer for small firms. In addition to learning-by-doing and learning-by-using, collective learning would enhance learning-by-interaction. In essence, this would require the transformation of a NID along three axes. The first of these is organizational change within firms. Theories of learning and innovation, as well as the theory of new competition (Best, 1990), stress new styles of management, new forms of work organization and human resources management. Inter-firm relations constitute the second axis. Not all types of inter-firm relations are conducive to learning: horizontal (user-producer and producer-client) relations are more conducive to learning than vertical subcontracting (Asheim, 1996). If the intensity of horizontal interaction in a district grows, learning by interaction may emerge. Once such a process is set in motion, the quality of the relationships can develop further, based on accumulated trust, sharing information, and so on. Relational contracting may emerge, as both parties invest further in their relationships. The third axis comprises the relationships between firms and the local regional economy and society. Here, Asheim refers primarily to the interaction between firms, universities and training centres and local public institutions.

According to Capello (1999), one may distinguish certain preconditions that define the transition from one form of local development situation to another. A geographical concentration, which may have emerged for whatever reason, may become a specialized area or a cluster if stable SME linkages emerge, and once a stable local labour market has developed. If these conditions are not satisfied, the area is likely to remain diversified. A specialized area may develop into a district when organizational and cultural proximity emerges. Such proximity and mutual acceptance of certain norms of reciprocity and respect contain opportunism and moral hazard and contribute to the reduction of transaction costs. Co-operation may emerge alongside competition. Deepening of the division of labour generates further economies of scale and scope leading to further 
integration. A full Marshallian district can grow, which may develop into a milieu if innovative synergies emerge between local firms and through the labour force. Collective learning begins to enhance the innovative capacity of the area. Once local actors realize the potential of collective learning and begin to exploit its advantages, as demonstrated by organizational innovations at the level of firm, network and level of governance, then the area has reached the stage of an innovative milieu.

So far, the argumentation has been inward oriented. Maskell, Malmberg and associates have made an interesting contribution to the debate (Maskell and Malmberg, 1999; Maskell et al., 1998), placing localized learning in the context of globalizing markets. Their central contention is that: 'Firms are progressively stimulated by and dependent on localized capabilities in order to maintain and increase their competitiveness precisely because of the drive towards globalization and the resulting homogenization of formerly critical factors of production' (Maskell and Malmberg, 1999: 168). Globalization destroys local capabilities that were based on previously important local production factors. Maskell and Malmberg argue that globalization also affects knowledge creation, but in a differentiated manner. Codified knowledge may be accessed anywhere on the globe (it becomes ubiquitous). Tacit knowledge creation requires organizational, cultural and spatial proximity. Locally embedded tacit knowledge therefore becomes a crucial source of localized capability. Differences in tacit knowledge between localities, regions and countries cannot easily be washed away by globalizing markets.

Localized capabilities are developed from four sources: infrastructure and built environment; natural resources of the area; specific institutional endowments; and knowledge and skills available in the area. Institutional endowments 'embrace all the rules, practices, routines, habits, custom and conventions associated with the regional supply of capital, land and labour and with regional markets for goods and services. These endowments are a product of history, of previous rounds of economic activity and set the stage for new rounds of localized knowledge creation (Maskell et al., 1998: 156).

How are these localized capabilities created? One important mechanism is the so-called 'first mover advantage'. This is similar to Krugman's head start mechanism of specialization but the authors add an evolutionary selection mechanism: those areas that have suitable local capabilities can better serve the needs of firms and thereby give them a better chance of survival. As the industry grows, more institutional development to suit these firms (for example in the areas of hard and soft infrastructure), training of the workforce and so forth, augments the competitive advantage of the area. A second mechanism is spin-off - new firm formation in the same lines of activity. A third mechanism is triggered by positive feedback loops arising from internal economies of scale and from agglomeration economies. Maskell et al. stress the importance of knowledge spillovers for localized learning. Other positive feedback comes from transaction cost advantages. 
Krugman assumed that specialization has an almost automatic cumulative path effect. Maskell and Malmberg (1999: 178) reject that idea: 'regions (must) rebuild obsolete structures, renew exhausted resources, restore decrepit institutions, revitalize outdated skills and replace inadequate knowledge'. In the age of globalization localized capabilities cannot be taken as permanent and enduring. Someone else will try to catch up and overtake, although there are certain factors that inhibit imitation.

Ideally, localized capabilities must be valuable, rare, not easily substituted and imperfectly imitated. Three mechanisms contribute to this. The first is what Maskell and Malmberg call 'asset mass efficiency': 'Regions that have a large stock of R\&D and experience-based knowledge, and a specialized labour force or infrastructure are often in a better position to make further breakthroughs which add to their existing stock of knowledge than regions which have a limited initial endowment of such factors' (Maskell and Malmberg, 1999: 176). A second mechanism is 'time compression diseconomy'. This basically implies that it takes considerable time to imitate institutional innovations and make them work, which discourages attempts to copy. Thirdly, local learning is characterized by inter-connectedness of asset stocks. That is to say, it involves a complex web of links across national, regional and local institutions as well as between institutions at each level. Thus, being able to reproduce one subset will turn out to be inadequate, as one will soon discover that other conditions need to be fulfilled as well.

Localized capabilities do not confer permanent advantage. Deterioration may result from reduced demand for the products of the industry. Widespread availability of industry knowledge and of production factors and imitation elsewhere may erode local advantages. Asset erosion may also be endogenous, for example, if new rounds of investment fail to materialize, or when there is ageing and a gradual redundancy of skills, bureaucratization of institutions (which lose their sense of mission), and the breaking up of (knowledge-creating) public-private partnerships under the impact of privatization. Capabilities may deteriorate due to substitution (such as IT) or lock-in, which occurs when previously successful institutions and firms resist change. As Olson argued many years ago (Olson, 1982), distributional coalitions of interest groups may appropriate gains and oppose change. Local elite, managers, trade unions and politicians may form alliances that prevent structural change in declining industries.

\section{Collective Learning in the South}

In comparison to clusters and districts, there are very few studies on localized learning and innovation in lower and middle-income countries, so it may be too early to judge the degree to which this perspective can assist in understanding local economic development. At first sight, and perhaps 
subject to gross oversimplification, conditions in many of these countries do not seem very conducive, though there may be substantial variation across continents (especially between Latin America and Asia on the one hand and Africa on the other). The industrial structure in many countries is characterized by a low degree of division of labour, with relatively few firms in individual market segments. Often a few large firms dominate. At the same time there is no middle segment and a large number of undifferentiated small producers, often concentrated in 'pre-industrial' clusters. Problems of trust and fragmented markets further complicate the emergence of inter-firm relations and subsequent learning.

Import-substitution processes pre-empted the need for learning as technology was adopted 'lock, stock and barrel' from advanced countries and markets were heavily protected, reducing the need and incentive to improve products to suit local demand (Helmsing, 1993). Firms were vertically integrated, incorporating the manufacture of some inputs and internalizing key producer services, and importing the remainder. Few were concerned about marketing, and many experienced 'sellers' markets'. Few firms were 'world class' or regional market leaders. Most were imitators in a technological sense and national innovation systems were weak. Low incomes meant that the role of 'demanding customers' was limited. Moreover, relatively affluent local people imitated western lifestyles, thereby enhancing the 'first mover' advantage of firms from the West.

After structural adjustment had liberalized international trade and domestic markets, firms in these countries became exposed to international and 'new' competition. In many countries structural adjustment had enhanced (or at least not diminished) the turbulence of macroeconomic conditions. In these circumstances of heightened uncertainty, vertical disintegration became a very risky strategy. Meyer-Stamer (1998) studied firmlevel strategies in the textile, engineering and ceramics industries in one state in Brazil. He found that firms initially persisted in vertical integration. Even though inefficient, it insulated them from the turbulent economic environment. Vertical disintegration would have made firms dependent on many other suppliers of inputs and service providers. As competing imports began to bite, many firms began to lose their market share. Only in the ceramics industry did a process of collective learning begin thanks to the role of the local business association (ibid.).

My own research in Bulawayo, Zimbabwe, also demonstrated that many firms in the mid-1990s resorted to strategies of 'belt tightening', 'economizing' and 'accepting lower profit margins', rather than engaging in more innovative strategies (Helmsing, 1998a). Periodic economic crises, caused by recurrent droughts, had turned defensive strategies into accepted and effective routines, at least for as long as a drought would last. After liberalization, more innovative strategies were required. The local situation in Bulawayo is still far removed from the conditions of an innovative milieu' (Helmsing, 1999b). 
The problem for countries in the South is how to prevent 'lock-in' into a role as low-wage producer, based on production platforms for TNCs. Upgrading is a necessity in order to generate higher wage employment. At the same time there is always the possibility that another country, in a 'race to the bottom', will offer even lower wages. The problems of upgrading remain real. The notion of collective learning offers exciting new avenues for upgrading, but as yet we know too little about these processes in local contexts of countries in the South.

\section{GOVERNANCE}

Economies are rapidly increasing in complexity. Firms not only depend on their own capacity to cope with this complexity, but draw on other firms and on support institutions as providers of inputs and services and as sources of learning and innovation. Problems of co-ordination have multiplied, while uncertainties about outcomes have increased. In order to reduce or to cope with these and associated problems (such as information asymmetries, moral hazard and opportunism), governance becomes a critical issue. This general argument can also be extended to the local level. Scott and Storper (1992: 22) formulated it as follows: 'Regions in which (such) coordination is weakly developed and in which unregulated competition prevails, face many problems and predicaments that compromise long-run viability. These regions are all the more vulnerable because, in a world of contested markets, they find themselves faced with competitors based in regions that provide effective regulatory and coordinating services'. In other words, the viability or strength of a regional production system depends as much on the firms as on the local regulatory, co-ordinating and supporting institutions and the way in which they interact. Systems that are better able to handle these problems have a greater capacity for timely adaptation and this allows them to maintain a growth trajectory. New forms of governance are required, both between firms as well as between firms and territorial or public agencies.

The governance of inter-firm relations has undergone rapid changes. New core concepts are networks (Hakanson, 1992; Thompson et al., 1991), commodity chains (Dicken, 1998), production systems (Scott and Storper, 1992), clusters (Porter, 1990, Schmitz, 1995a) and business systems (Whitley, 1992). Relations between firms have been conceptualized in a great variety of ways, using different logics and scales, including sector-level organization - consisting of associations which provide common services and engage in selfregulation - and organization at industry level, which consists of different types of producers involved in one production column or commodity chain. An industry may cut across several sectors. The size or scale of such an organization may vary considerably. It may be highly selective, specific to a limited number of firms, or seek to be broadly representative of all relevant firms. 
Territorial governance in general and local governance in particular have entered the scene of economic development. While two decades ago central government was considered to be the principal actor, this changed rapidly in the late-1980s and early-1990s. The NID and learning literature in particular has emphasized the role of local and regional governments in cluster development and in creating an innovative milieu. This recognition is important but should not lead to a new kind of myopia, a failure to take account of other dimensions, especially at industry and at (inter)national levels. In the following subsections, I will attempt to highlight some key issues in an effort to unravel the governance of local economic development.

\section{Governance of Inter-Firm Relations}

Three specific issues have received considerable attention in the literature on local economic development. The first relates to common services, the second to business associations, and the third to industrial policy frameworks.

For local producers to gain access to global markets, they generally require specialist producer services to enable them to acquire knowledge about these markets (demand characteristics such as consumer tastes and product attributes, marketing channels and trading practices). They also need these services in order to prepare their own manufacturing operations financially, technologically and organizationally for internationally competitive production. Large firms may be able to marshal the resources to engage in the necessary market development and associated product development efforts. Small and medium enterprises, however, often have to gain access to external resources and rely on specialist business service providers to obtain market and product information, tools and technologies, skills and so on.

We saw earlier that specialist services form one of the (market-based) externalities arising from agglomeration. However, the NID literature has stressed the crucial role of inter-firm co-operation in generating specialist services on a non-market basis (Brusco, 1989). In some of the Italian districts, governments played a prominent role in supporting the creation of these services. In the archetypal industrial district of Emilia Romagna, the regional development agency set up a network of general, sector-specific and function-specific centres to provide services to the garment and domestic electrical appliances sectors. These centres were managed jointly with local business associations (Cooke and Morgan, 1994, 1998). In his studies of European and Brazilian industrial districts, Schmitz also identifies the importance of joint action for common services, emphasizing the 'public' or rather 'club good' and non-market character of these services.

Reviewing the literature one may find a wide range of institutional modalities for specialist services including: (i) public provision, where public 
agencies provide services such as export marketing, vocational training and technology centres; (ii) public-private partnerships where government, for example (co-)finances service centres but leaves it to the private sector to run them (trade representation, sector specific innovation centres); (iii) intermediary forms of non-profit (non-membership) enterprise promotion agencies delivering enterprise development services (such as Carvajal Foundation in Colombia, and the much quoted Steinbeis Foundation, Germany); (iv) business associations (as in the case of the footwear cluster in Brazil); (v) consortia (more or less formalized agreements between a limited number of firms to pool efforts or resources for a common purpose); usually these are not sector-wide but composed of self-selected groups of firms (examples may be found in the area of export marketing, credit and procurement and sourcing of inputs; see Best, 1990); (vi) formation of groups of firms, often restricted to small groups, and often involving flexible arrangements, such as joint tendering for export orders, or joint procurement and sourcing of inputs - the 'Grupo Exportadora' in Caldas is a group of garment export firms in this mould (Helmsing, 1998b). The question of which delivery modalities are the most appropriate for particular common services under specific local economic conditions is as yet unresolved.

Recently, Schmitz reformulated his concept of collective efficiency in an attempt to cope at least partially with this institutional variation. He made a distinction between horizontal and vertical co-operation and between bilateral and multilateral forms of inter-firm collaboration (Schmitz, 1999a). This suggests that size (bilateral versus multilateral) and type of cooperation matter. Collective action theory provides additional clues. Besides size of group, it identifies the object of collective action and the characteristics of the object of collective action, the common service.

The multiple roles of business associations (BAs) in economic development are increasingly recognized. Associations may take a variety of forms (Levitzky, 1993, 1994). Traditionally, they represent their members in their dealings with government, lobby for more favourable economic policies, and often negotiate collective wage agreements with trade unions. Their other traditional function is a social one: an association provides a reference group for individual entrepreneurs. More recently, the emphasis shifted to two other functions - the provision of real services and what Streeck and Schmitter (1985) called 'private interest governance'. The literature on NIDs, as we saw earlier, provides ample evidence of services, such as information, training, technology and marketing. Private interest governance refers to regulatory functions performed by associations, especially establishment of norms and standards for products, best practices and codes of conduct. The associations can also resolve conflicts of interest between firms.

The expanding role played by BAs may be due to several factors. The first is the transformation of the role of the state in economic development. Neo-liberal thinking, which gained ground in the 1980s and early-1990s, 
induced national states to reduce their interventionist economic policies. Market forces were expected to provide better solutions to the problems of economic growth. Since then, there has been a growing realization that market responses are not automatically forthcoming. This market failure may have a variety of causes (high up-front investment costs or risks, low demand, the public and 'club' good character of the necessary provisions, knowledge barriers, and so on). To avoid the old trap of government failure, new forms of governance are advocated. These have in common that they are demand led, 'at arm's length', and enabling. The latter implies that government shares implementation with, or delegates it to, other actors. In this context, business associations are one of the key actors articulating concerns and demands of producers, pooling resources and providing (semi-) public and 'club' goods (cf. Best, 1990; Humphrey and Schmitz, 1996; Maskell et al., 1998; Meyer-Stamer, 1997).

Second, the globalization of economic activity has considerably increased the complexity of the environment in which firms operate and they need access to specialist business services. As we have already seen, BAs provide such services, thus contributing to 'collective efficiency'. They constitute a crucial dimension of the 'institutional thickness' of industrial districts and are considered important components of local social capital (Amin and Thrift, 1994). Third, in the face of rapid technological change, firms need to continuously upgrade their capabilities. Although much technological knowledge is codified and increasingly globally accessible, use and successful adaptation to local circumstances requires crucial tacit knowledge (Maskell et al., 1998; Raco, 1999). Partly, firms can acquire this on the basis of their own resources, but smaller and less experienced firms need to draw on external resources in order to learn. Associations help to develop the preconditions necessary for 'collective learning' (Keeble et al., 1999). They function as channels through which local producers seek to acquire crucial tacit knowledge, either directly or indirectly via BAs in other countries. Meyer-Stamer (1997) and Barzelay (1991) document cases of local producers in ceramic and marble extraction and in the building materials industry in Brazil and Spain respectively. Through local business associations linking up with business associations in Italy, they obtained 'role models' on how to reorganize their industry and bring their own practices up to world standards. Associations may be conduits through which firms 'learn by interaction' (Morgan, 1997; Raco, 1999).

Observers have noted a growing proliferation of business associations in developing and newly industrializing countries (Moore and Hamalai, 1993). My own research on processes of local economic restructuring has demonstrated that new associations have been formed in Zimbabwe (Helmsing, 1998a) and that firms in Colombia have become members of various associations at the same time (Helmsing, 1998b). Moore and Hamalai consider the liberalization of economies and the loosening of controls on political expression and organization as important factors. They emphasize 
the 'collective entrepreneurial drive' on the part of the managers of these associations. This is no doubt important but takes insufficient account of the expanding roles associations perform in service provision, learning and industrial governance.

While associations can play a positive role, they can also contribute to a 'lock-in', in the sense that they adhere to existing routines and practices and are unable to change and make use of new opportunities. Success and status achieved in the past (for example, in the era of import-substitution industrialization) may cause resistance to change. A more political economic explanation of 'lock-in' would apply when an association is controlled by small groups of 'interlocking' firms and/or families who enjoy substantial benefits from their current positions of influence and who resist losing them when the benefits of change are uncertain.

Best has been a strong advocate of industrial policy in the context of new competition. In his view, strategic industrial policy on the part of government should have a production rather than a distribution focus, seeking to shape markets, stimulating and undertaking complementary investments in business support systems, and encouraging firms to develop strategic alliances. The purpose of such a policy would be to promote 'Schumpeterian' competition. This means, in part, shaping markets and affecting the form that competition takes in order to enhance economic performance. This would be based on: (i) a strong anti-trust and pro-competition policy; (ii) the promotion of inter-firm networks and of a balance between cooperation and competition; (iii) primacy of strategy over planning whereby strategies are not designed by planners but in concert with industry leaders; and (iv) not 'picking winners' but adopting an open sector orientation. Sector-specific policies are less prone to special interest politics and less corrosive of the consensus and mutual responsibility required to develop and implement sector strategies (Best, 1990).

Bennet and McCoshan (1993) go somewhat further and argue that the key challenge is to develop greater systems rationality. A national consensus of industrial priorities needs to be developed in a continuous encompassing process, which includes not only the key ministry concerned and national business organizations but also the participation of sectors and agencies providing key inputs in the business environment (economic, physical infrastructure). A key question here is how clusters and industrial districts can best be incorporated, via sector or via territory.

Meyer-Stamer (1997), discussing industrial change in Brazil, comes very close to Bennett and McCoshan when he argues the notion of 'systemic competitiveness'. 'Sustained industrial competitiveness rests not only on firm's capabilities (micro) and a stable macro economic framework, but also and in particular on a tissue of supporting, sector-specific and specialized institutions and targeted policies (meso) and on governance structures that facilitate problem solving between state and societal actors (meta)' (Meyer-Stamer, 1997: 369). Here, the government acts as co-ordinator, moderator and 
communicator in policy networks with firms, their associations, trade unions and intermediary organizations in science and technology and in training. Successful policy networks depend, among other things, on the autonomy of collective actors, who are capable of resolving internal conflicts of interest; have trust and a commitment to fair exchange and an orientation towards substantial outcomes, joint decision-making and information sharing.

\section{Localized Economic Governance}

Several trends have contributed to a localization of economic governance. First, in many countries it has been realized that in order to make national innovation and support systems more responsive, they must be decentralized. Second, the roles of local governments have increased for a number of reasons. This is in itself a complex process and several factors are involved.

Starting with the first issue, Bennet and McCoshan (1993) argue that local co-ordination is the key. Although many support systems are nationally organized for reasons of scale and efficiency and cannot be completely decentralized, implementation takes place at local level. They argue that the participation of local actors and firms leads to a better appreciation of specific needs and problems. Networks must be organized locally and 'are meant to integrate vertical programs and facilitate the flow of information about opportunities and about resources that need to be mobilized to seize these'. Networks facilitate external effects of economic decision-making to become internalized by better attuning decisions to each other, and by preventing negative and maximizing positive externalities. The authors distinguish various types of local economic development networks and examine network dynamics. They observe that the capacity to develop LED networks varies widely by region, depending on the diversity of their economic structures and the level of economic development.

Cooke and Morgan (1998) arrive at a similar conclusion but from a different perspective. Their main contention is that in order to become successful in learning and innovation, firms have to develop associational capacities, at the level of the firm (between managers and workers), at the level of inter-firm co-operation and the commodity chain and at the level of enterprise support systems. The main challenge is to get the interaction right between these three elements. The region can perform strategic enterprise support functions that cannot easily be provided centrally. The national level is too high to cope with complexity and detail, while the regional level allows for an appropriate incorporation of local diversity and specificity. Local governance structures must be forged which facilitate co-ordination and convergence across these three elements.

With regard to the second issue, several factors have contributed to a more prominent role for local government in local economic development. First, there has been a generalized and persistent trend towards decen- 
tralization in the public sector, which has complex and multiple causes (cf. Helmsing, 1996). By now, the vast majority of developing countries and transitional economies are engaged in processes of decentralization and strengthening their local governance structures. Public responsibilities have been transferred to local governments, but usually without adequate transfer of resources. The need to generate more local revenues has forced local governments to take more interest in the economic development of their area of jurisdiction - although the concern for local economic development does not only derive from the need to raise revenue, but is also a response to the preferences of local people and enterprises. Second, in a number of countries new legislation has facilitated the entry of local governments into public-private partnerships (for example, South Africa, Uganda, and Bolivia). Third, changing perceptions on social security and poverty alleviation have made local government more active in pursuing local employment creation (Bennett, 1990). Fourth, in a number of countries, national or state governments have launched support programmes to enable local governments to become more active in local economic development. Finally, in a number of countries, there have been genuine regionalist pressures which stem from political demands in response to past neglect, but which may also arise from the build-up of local initiatives in association with successful processes of local specialization (Cooke and Morgan, 1998). The industrial district literature has documented and given some credibility to local and regional government involvement, especially in relation to economic regulation, infrastructure, social services and housing and support services (Brusco and Righi, 1989).

In stark contrast to past practices at national level, local governments generally realize that they are but one of many players involved in local economic development. Most local authorities, also in relatively affluent countries, spend a fairly small proportion of their budgets on direct economic development support. More important, however, are the manner in which they discharge their main functions, and whether they realize their economic significance as (i) a source of economic opportunity and (ii) a service enhancing or inhibiting enterprise development and competitiveness (Bennett and McCoshan, 1993). Many studies of NIDs stress the limited role of local governments: their initiatives have rarely played a decisive role in the economic development of the clusters (Meyer-Stamer, 1998; Schmitz, 1992, 1995a; Visser, 1996). Cooke and Morgan (1998: 23) define this role as follows: 'The [local] state is to create the conditions whereby firms, intermediary organizations and public agencies can engage in a self-organized process of interactive learning'.

Local actors are best placed to assess their own situation and learn by comparing with other experiences. Learning at the regional level involves institutional and organizational processes. This is what Lawson (1999) conceptualized as a new local or regional competence. It requires an ability to spot signs of change; to create awareness and communicate it to other actors 
so that all understand the implications; and lastly, it requires a responsiveness to mobilize resources to address emerging problems. Essentially this is a case of collective learning, but now at local governance level.

A regional innovation system (RIS) is a system in which universities, research organizations, vocational training agencies, technological transfer institutions and financial institutions interact with local industries. This contributes to greater systemic rationality, and is capable of generating substantial efficiencies in the enterprise support system, by reducing policy mismatches and by creating greater convergence in complementary investment and support programmes. A RIS, if properly structured, can contribute to collective learning at the level of local and regional policy-making. It can assist in a social and economic intelligence function by contributing to three feedback loops (Cooke and Morgan, 1998): (i) assessing the extent to which the economic trajectory of a region is appropriate; (ii) comparing the region's performance with other and 'peer' systems; and (iii) working out the implications for changes in the system in order to prevent a lock-in (for example, in the orientation of and priorities for the enterprise support, training and human resource development).

As an area continues to specialize and organizes its social institutions and support systems to enhance this, it may become prone to a 'lock-in' as it becomes progressively unable to change trajectory. Globalization of trade and the growing mobility of production make restructuring a more frequent problem of new local economic development. Too strong an interdependence between local firms and local territorial institutions may create a 'lockin', which may have disastrous consequences for adaptability. Grabher (1993) studied lock-in of the Ruhr region, the coal-mining, iron and steel region which was once the industrial heartland of Germany. He identified three processes: (i) functional lock-in, where firms have invested so much in developing relationships with their current customers and suppliers (highasset specificity) that they resist switching, even though these relations have ceased to be profitable; (ii) cognitive lock-in, when firms cease to look beyond their current business and markets; and (iii) political lock-in, when the system is kept on course thanks to intensive and consensual political decision-making in support of the current firms and their trajectories: this worked effectively but brought the system to a dead-end (Grabher, 1993). This is a general illustration of the point that industrial and territorial governance structures may be a source of additional higher level competence, enhancing the local capability of firms and support systems, but also they may become a contributing factor towards lock-in and recession.

\section{FINAL OBSERVATIONS}

The creation of local externalities has become an area of policy. Firms in localities and regions which have generated positive externalities and reduced 
negative externalities, have an advantage over others located elsewhere. External economies continue to figure but the source and weight have shifted. At first, the emphasis was on market-based external economies, initially those associated with production, and later those originating in the transaction sphere. However, more recently, non-traded interdependencies have gained in significance. These include: common services organized by joint action; norms and standards, and codes of conduct arranged through public and private interest governance; and the importance of trust and social embeddedness of networks. In all, grounded institutions that complement and organize markets constitute a (non-tradable) territorially specific asset: a localized capability (Maskell et al., 1998).

Evolutionary perspectives and the premises of the 'knowledge-based' economy have introduced a new local dimension. The learning perspective on regional policy aims at change and restructuring, and seeks to augment the ability of firms, industries, clusters and regions to accumulate and utilize knowledge (Raco, 1999). It enhances a multitude of competencies in both private and public institutions and promotes the integration of such knowledge. Collective learning is a new resource for firms. Spatial proximity plays a role, alongside organizational and cultural proximity. It takes place through inter-firm co-operation, through the labour market and mobility of workers, and through spin-offs into new firms. Externalities, spillovers and non-market exchanges of information and skills characterize collective learning.

Collective learning also refers to the interaction between firms and territorial institutions that regulate and/or are responsible for support systems like training centres, universities, information and technology institutes, and other specialist services. Networking, greater systems rationality and convergence in their investment and delivery programmes may constitute another source of local advantage. Two points should be stressed here - first, that this does not refer only to local institutions but also to decentralized sector, industry and national agencies; and second, that a (supply-driven) increase in the number of local institutions does not automatically generate more collective learning or competitiveness. It takes two to tango. The demand for collective learning and the participation by entrepreneurs themselves is critical (Schmitz, 1999b).

In its turn, collective learning may generate new forms of local economic governance. These may consist of public or private forms, as well as partnerships. In many countries there has been a veritable explosion of differently constituted local economic development agencies, fora, platforms, commissions, and so on, that play a role in co-ordination, promotion and support. Specialization and localized learning may thus lead to the development of new tailor-made institutions, which in their turn enhance local capabilities. The broadening of the local institutional base is one of the central messages on local economic development (Amin, 1999).

These features come close to what Maillat (1998) argues in relation to the innovative milieu. He stresses the importance of involving local players and 
the development of localized synergies leading to new endowments or (nonphysical) territorial assets. Synergies may compensate for the lack of local economies of scale, cut transaction costs and develop specific and collective territorial resources (in the form of know-how, specific technologies, products and processes).

The initial focus may be on particular concentrations of products and industries (clusters), but what matters in the end are 'deeper' local regional competencies. These include new firm formation (start-ups) and upgrading, the associative capacity of firms, labour mobility and the development of local human resources, synergy between economic activities, the 'thickness' of local institutions and of support systems, and the convergence in their programmes. There is path and context dependence (Lambooy, 1998).

The context for local economic development policy in the South is quite different from that prevailing in the North, although there are also significant differences amongst Southern countries and regions. Earlier we noted the large differentiation of clusters. We have also looked at collective learning in the South. Firms are, quite often, locked into 'old' routines associated with import substitution, and/or operate in an environment which is economically, socially and politically not conducive to collective learning or to the adoption of institutional innovations associated with NIDs and innovative milieus. In many countries economic development will become even more uneven in geographical terms.

It is fair to say that we are moving towards a new generation of local and regional policies. This new generation of policies is, on the one hand, a response to the further study and evaluation of endogenous regional development and policies through NIDs and based on new perspectives of collective learning. They result from the recognition that globalization makes territorial production systems and not just companies compete with each other. This means that new policies cannot be exclusively local but must take into account the position and the positioning of territorial production systems within a local-global context. New policies supersede the opposition between exogenous and endogenous development policies (Helmsing, 1999a, 1999b).

\section{REFERENCES}

Altenburg, T. and J. Meyer-Stamer (1999) 'How to Promote Clusters: Policy Experiences from Latin America', World Development 27(9): 1693-713.

Amin, A. (1999) 'An Institutionalist Perspective on Regional Economic Development', International Journal of Urban and Regional Research 23(2): 365-78.

Amin, A. and N. Thrift (1994) Globalization, Institutions and Regional Development in Europe. Oxford: Oxford University Press.

Asheim, B. T. (1992) 'Flexible Specialization, Industrial Districts and Small Firms: A Critical Appraisal', in H. Ernste and V. Meier (eds) Regional Development and Contemporary Industrial Response: Extending Flexible Specialization, pp. 45-56. London: Belhaven Press. 
Asheim, B. T. (1996) 'Industrial Districts as “Learning Regions”: A Condition for Prosperity', European Planning Studies 4(4): 379-400.

Barzelay, M. (1991) ‘Managing Local Development: Lessons from Spain', Policy Sciences 24(3): 271-90.

Bell, M. and M. Albu (1999) 'Knowledge Systems and Technological Dynamism in Industrial Clusters in Developing Countries', World Development 27(9): 1715-34.

Bennett, R. J. (1990) Decentralization, Local Governments and Markets. Towards a Post-Welfare Agenda. Oxford: Oxford University Press.

Bennett, R. J. and A. McCoshan (1993) Enterprise and Human Resource Development: Local Capacity Building. London: Paul Chapman.

Best, M. H. (1990) The New Competition. Institutions of Industrial Restructuring. Cambridge: Polity Press.

Boddy, M. (1999) 'Geographical Economics and Urban Competitiveness: A Critique', Urban Studies 36(5/6): 811-42.

Brusco, S. (1989) ‘A Policy for Industrial Districts', in E. Goodman and J. Bamford (eds) Small Firms and Industrial Districts in Italy, pp. 259-69. London: Routledge.

Brusco, S. and E. Righi (1989) 'Local Government, Industrial Policy and Social Consensus: The Case of Modena (Italy)', Economy and Society 18: 406-24.

Camagni, R. (1991) 'Local Milieu, Uncertainty and Innovation Networks: Towards a New Dynamic Theory of Economic Space', in R. Camagni (ed.) Innovation Networks: Spatial Perspectives, pp. 121-45. London: Belhaven Press.

Capello, R. (1999) 'Spatial Transfer of Knowledge in High Technology Milieux: Learning versus Collective Learning Processes', Regional Studies 33(4): 353-65.

Cawthorne, P. M. (1995) 'Of Networks and Markets: The Rise and Rise of a South Indian Town, the Example of Tiruppur's Cotton Knitwear Industry', World Development 23(1): 43-56.

Cooke, P. and K. Morgan (1994) 'Growth Regions under Duress: Renewal Strategies in Baden Württemberg and Emilia-Romagna', in A. Amin and N. Thrift (eds) Globalization, Institutions and Regional Development in Europe, pp. 91-117. Oxford: Oxford University Press.

Cooke, P. and K. Morgan (1998) The Associational Economy: Firms, Regions and Innovation. Oxford: Oxford University Press.

Das, K. (1998) 'Collective Efficiency and Firm Strategy: Study of an Indian Industrial Cluster', Entrepreneurship and Regional Development 10: 33-49.

Dicken, H. (1998) Global Shift (3rd edn.). London: Paul Chapman.

Grabher, G. (1993) 'The Weakness of Strong Ties. The Lock-in of Regional Development in the Ruhr Area', in G. Grabher (ed.) The Embedded Firm. On the Socio-economics of Industrial Networks, pp. 255-78. London: Routledge.

Hakanson, H. (1992) 'A Model of Industrial Networks', in B. Axelson and G. Easton (eds) Industrial Networks: A New View of Reality, pp. 28-34. London: Routledge.

Helmsing, A. H. J. (1993) 'Small Enterprise and Industrialisation Policies in Africa: Some Notes', in A. H. J. Helmsing and Th. Kolstee (eds) Small Enterprises and Changing Policies. Structural Adjustment, Financial Policy and Assistance Programmes in Africa, pp. 24-38. London: Intermediate Technology Publishers.

Helmsing, A. H. J. (1996) 'South Africa: Post-Apartheid Restructuring of Government Which Way? Reflections on International Experiences', in A. H. J. Helmsing et al. (eds) Restructuring the State and Intergovernmental Fiscal Relations in South Africa, pp. 25-48. Johannesburg: FES in association with the Graduate School for Public and Development Management, University of Witswatersrand.

Helmsing, A. H. J. (1998a) 'Survey of Economic Restructuring and Competitiveness of Manufacturing Industries, Bulawayo, Zimbabwe, 1992-1995'. Research Report. The Hague: Institute of Social Studies (mimeo).

Helmsing, A. H. J. (1998b) 'Survey of Economic Restructuring and Competitiveness of Manufacturing Industries, Armenia, Manizales and Pereira, Colombia, 1993-1996'. Research Report. The Hague: Institute of Social Studies (mimeo). 
Helmsing, A. H. J. (1999a) 'Teorias de desarrollo industrial regional y políticas de segunda y tercera generación', Revista Latinoamericana de Estudios Urbano Regionales (EURE) 25(75): 5-39.

Helmsing, A. H. J. (1999b) 'Competitive Response, Innovation and Creating an Innovative Milieu: The Case of Manufacturing Industry in Bulawayo, Zimbabwe'. Working Paper No 291. The Hague: Institute of Social Studies.

Humphrey, J. (1995) 'Industrial Organization in Developing Countries: From Models to Trajectories', World Development 23(1): 149-62.

Humphrey, J. and H. Schmitz (1996) 'The Triple C Approach to Local Industrial Policy', World Development 24(12): 1859-77.

Keeble, D., C. Lawson, B. Moore and F. Wilkinson (1999) 'Collective Learning Processes, Networking and Institutional Thickness in the Cambridge Region', Regional Studies 33(4): 319-32.

Knorringa, P. (1996) The Economics of Collaboration. New Delhi: Sage Publications.

Knorringa, P. (1999) 'Agra: An Old Cluster facing New Competition', World Development 27(9): $1587-604$.

Krugman, P. (1991) Geography and Trade. Leuven: Leuven University Press.

Krugman, P. (1994) 'Competitiveness: A Dangerous Obsession', Foreign Affairs 73(2): 28-44.

Krugman, P. (1995) Development, Geography and Economic Theory. Cambridge, MA: MIT Press.

Krugman, P. (1998a) 'Space: The Final Frontier', Journal of Economic Perspectives 12(2): $161-74$.

Krugman, P. (1998b) 'What's New about the New Economic Geography?', Oxford Review of Economic Policy 14(2): 7-17.

Lambooy, J. (1998) 'Learning and Agglomeration Economies: Adapting to Differentiating Economic Structures'. Paper presented at the Conference on Learning Regions, Tilburg University (March).

Lawson, C. (1999) 'Towards a Competence Theory of the Region', Cambridge Journal of Economics 23: 151-66.

Lawson, C and E. Lorenz (1999) 'Collective Learning, Tacit Knowledge and Regional Innovative Capacity', Regional Studies 33(4): 305-17.

Levitsky, J. (1993) 'Private Sector Organizations and Support for Small and Micro Enterprises', in A. H. J. Helmsing and Th. Kolstee (eds) Small Enterprises and Changing Polices, pp. 31840. London: Intermediate Technology Publications.

Levitsky, J. (1994) 'Business Associations in Countries in Transition to Market Economies', Small Enterprise Development 5(3): 24-34.

Maillat, D. (1995) 'Territorial Dynamic, Innovative Milieus and Regional Policy', Entrepreneurship and Regional Development 7: 157-65.

Maillat, D. (1998) 'Innovative Milieux and New Generations of Regional Policies', Entrepreneurship and Regional Development 10: 1-16.

Markusen, A. (1996) 'Sticky Places in Slippery Space: A Typology of Industrial Districts', Economic Geography 72: 293-314.

Martin, R. and P. Sunley (1996) 'Paul Krugman's Geographical Economics and its Implications for Regional Development Theory: A Critical Assessment', Economic Geography 72: 259-93.

Maskell, P. and A. Malmberg (1999) 'Localized Learning and Industrial Competitiveness', Cambridge Journal of Economics 23: 167-85.

Maskell, P., H. Eskelinen, I. Hannibaldson, A. Malmberg and E. Vatne (1998) Competitiveness, Localized Learning and Regional Development. Specialization and Prosperity in Small Open Economies. London: Routledge.

McCormick, D. (1999) 'African Enterprise Clusters and Industrialisation: Theory and Reality', World Development 27(9): 1531-51.

Meyer-Stamer, J. (1997) 'New Patterns of Governance for Industrial Change: Perspectives from Brazil', Journal of Development Studies 33(3): 364-91. 
Meyer-Stamer, J. (1998) 'Path Dependence in Regional Development: Persistence and Change in Three Industrial Clusters in Santa Catarina, Brazil', World Development 26(8): 1495-511.

Moore, M. and L. Hamalai (1993) 'Economic Liberalisation, Political Pluralism and Business Associations in Developing Countries', World Development 21(12): 1895-912.

Morgan, K. (1997) 'The Learning Region: Institutions, Innovation and Regional Renewal', Regional Studies 31(5): 491-503.

Myrdal, G. (1957) Economic Theory and Underdeveloped Regions. London: Duckworth.

Nadvi, K. M. (1996) 'Small Firm Industrial Districts in Pakistan'. DPhil Thesis. Brighton: University of Sussex.

Nadvi, K. M. (1999) 'The Cutting Edge: Collective Efficiency and International Competitiveness in Pakistan', Oxford Development Studies 27(1): 81-107.

Nelson, R. P. and S. G. Winter (1982) An Evolutionary Theory of Economic Change. Cambridge, MA: The Belknap Press of Harvard University Press.

Olson, M. (1982) The Rise and Decline of Nations. Westford, MA: Murray.

Pedersen, P. O., A. Sverisson and M. P. Van Dijk (eds) (1994) Flexible Specialization. The Dynamics of Small-scale Industries in the South. London: Intermediate Technology Publications.

Piore, M. and Ch. Sabel (1984) The Second Industrial Divide: Possibilities for Prosperity. New York: Basic Books.

Porter, M. E. (1985) Competitive Advantage. New York: The Free Press.

Porter, M. E. (1990) The Competitive Advantage of Nations. New York: The Free Press.

Rabellotti, R. (1995) 'Is there an "Industrial District Model"? Footwear Districts in Italy and Mexico Compared', World Development 23(1): 29-41.

Rabellotti, R. (1999) 'Recovery of a Mexican Cluster: Devaluation Bonanza or Collective Efficiency', World Development 27(9): 1571-85.

Rabellotti, R. and H. Schmitz (1999) 'The Internal Heterogeneity of Industrial Districts in Italy, Brazil and Mexico', Regional Studies 33(2): 97-108.

Raco, M. (1999) 'Competition, Collaboration and the New Industrial Districts: Examining the Institutional Turn in Local Economic Development', Urban Studies 36(5/6): 951-68.

Scott, A. J. (1988) 'Flexible Production Systems and Regional Development: The Rise of New Industrial Spaces in North America and Europe', International Journal of Urban and Regional Research 12(2): 171-87.

Scott, A. J. and M. Storper (1992) 'Regional Development Reconsidered', in H. Ernste and V. Meier (eds) Regional Development and Contemporary Industrial Response: Extending Flexible Specialization, pp. 3-24. London: Belhaven Press..

Schmitz, H. (1992) 'Industrial Districts: Model and Reality in Baden Württemberg, Germany', in F. Pyke and W. Sengenberger (eds) Industrial Districts and Local Economic Regeneration, pp. 87-121. Geneva: ILO.

Schmitz, H. (1995a) 'Small Shoemakers and Fordist Giants: Tale of a Super Cluster', World Development 23(1): 9-28.

Schmitz, H. (1995b) 'Collective Efficiency: Growth Path for Small-scale Industry', Journal of Development Studies 31(4): 529-61.

Schmitz, H. (1999a) 'Collective Efficiency and Increasing Returns', Cambridge Journal of Economics 23: 465-83.

Schmitz, H. (1999b) 'Global Competition and Local Cooperation: Success and Failure in the Sinos Valley, Brazil', World Development 27(9): 1627-50.

Storper, M. (1990) 'Industrialization and the Regional Question in the Third World: Lessons of Post-imperialism; Prospects of Post-Fordism', International Journal of Urban and Regional Research 14(3): 423-45.

Streeck, W. and P. C. Schmitter (eds) (1985) Private Interest Governance. London: Sage Publications.

Thompson, G., J. Frances, R. Levacic and J. Mitchell (eds) (1991) Markets, Hierarchies and Networks. The Coordination of Social Life. London: Sage Publications in assoc. with the Open University. 
Visser, E. J. (1996) 'Local Sources of Competitiveness — Spatial Clustering and Organizational Dynamics in Small-scale Clothing in Lima, Peru'. PhD thesis, University of Amsterdam.

Visser, E. J. (1999) 'A Comparison of Clustered and Dispersed Firms in the Small-scale Clothing Industry of Lima', World Development 27(9): 1553-70.

Whitley, R. (1992) 'Societies, Firms and Markets: The Social Structuring of Business Systems', in R. Whitley (ed.) European Business Systems: Firms and Markets in their National Context, pp. 5-45. London: Sage Publications.

Weiland, H. (1999) 'Microenterprise Clusters in Rural Indonesia: Industrial Seedbed and Policy Target', World Development 27(9): 1515-30.

Bert Helmsing is professor of Local and Regional Development at the Institute of Social Studies (PO Box 29776, 2502 LT The Hague, The Netherlands) and professor of Local and Regional Planning at the University of Utrecht. He has published a number of books and articles on issues of local and regional development and planning, in the last ten years focusing particularly on small enterprise development and decentralization and local government finance. His current research interests focus on networking in local economic development and on evaluation of decentralization reforms. 